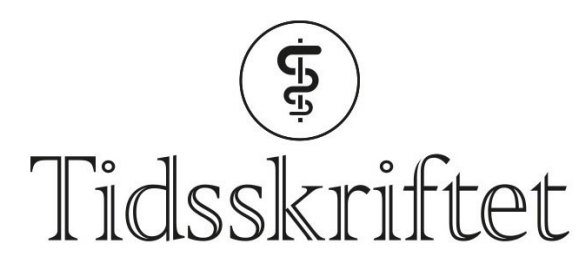

DEN NORSKE LEGEFORENING

\title{
Morten Laudal
}

MINNEORD

BENTE ASCHIM

SIGNE FLOTTORP

ARTHUR HERTZBERG

SVERRE LUNDEVALL

ANNE KATHRINE NORE

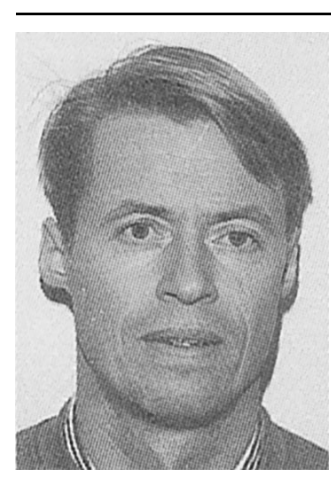

Morten Laudal døde 2. september 2017, 63 år gammel. Han var fastlege og kommunelege i Vestby og gjorde i en årrekke en stor innsats i mange viktige verv i Legeforeningen. For sitt engasjement for fagutvikling i norsk allmennmedisin fikk han prisen Årets allmennlege i 2017.

Vi fem ble tidlig kjent med Morten. Siden 1989 har vi hatt en kollegagruppe av allmennleger med regelmessige møter om faget og om livet. Der har vi drøftet medisinskfaglige spørsmål, sett video av hverandres pasientkonsultasjoner og delt suksesser og tabber, undring og faglig ubehag.

Der enkelte av oss kunne henfalle til grubling over alt det ugreie, var Morten den løsningsorienterte og nevenyttige. Han var et arbeidsjern med kapasitet til å sette seg grundig inn i faglige og helsepolitiske spørsmål. På dette grunnlag utformet han klare meninger som han fremførte med stor energi både på våre gruppemøter og ellers. Han var likevel åpen og nysgjerrig og møtte andres synspunkter med velvilje. Da sa han ofte med et vennlig ansikt: «Å jasså, du?»

En viktig del av allmennlegens diagnostikk er den kliniske undersøkelsen. Kvaliteten på håndverket, legens praktiske ferdigheter, må holdes ved like. På dette området var Morten 
en ener og et forbilde, så flink med hendene at vi kunne undre oss over hvorfor han var blitt allmennlege og ikke kirurg. Svaret ligger kanskje i hans brede interessefelt.

En av hans mange interesser var geriatri og sykehjemsmedisin. Morten har lært oss om vanskelige avgjørelser en sykehjemslege må ta, og hvor viktig legens kontinuitet og tilgjengelighet er for å trygge beboere, pårørende og personale.

I de senere år ble Morten bekymret for helsevesenets tendens til overbehandling og overdiagnostikk. Han advarte mot medikalisering som kan føre til unødige undersøkelser og behandlingstiltak, unødige plager og unødige bekymringer. Han arbeidet for at norsk allmennmedisin skal fremme kloke valg og være en del av den internasjonale trenden som kalles «choosing wisely».

Vårt samvær har ikke bare vært faglig. På årlige turer til hytta på Mylla var Morten i sitt ess. Han var med glede sjefsplanlegger og sjefskokk for tallrike utsøkte måltider. Og han preparerte med like stor glede alles ski i sin oppfinnsomt selvinnredede, praktiske og velutstyrte smørebu.

Kreftdiagnosen ble stilt for litt under ett år siden. Med sin medisinske innsikt forsto han hvordan dette ville gå, men at moderne cellegiftbehandling kunne gi ham litt ekstra tid. Denne tiden brukte han godt.

Vi har hatt enorm glede av alt Morten tilførte gjennom årene. Det er både uvirkelig og trist at denne energiske, livsglade og sterke mannen ikke er med oss mer. Sorgen er dyp og savnet er stort. Våre tanker går til Taran, Michelle og Oscar.

Publisert: 13. november 2017. Tidsskr Nor Legeforen. DOI: 10.4045/tidsskr.17.0883

(C) Tidsskrift for Den norske legeforening 2020. Lastet ned fra tidsskriftet.no 